\title{
Accounting Systems in Small and Micro Enterprises in Kenya
}

\section{Beth Wanjeri Mwangi}

\begin{abstract}
:
For a long time in Kenya, the practices and principles of accounting have been viewed to be for use by corporate and other formally structured organizations. This paper seeks to investigate what accounting means to small and micro traders in Kenya, by reviewing the practices and principles they use in running their businesses. Indeed, little attention has been paid to accounting systems in small and micro enterprises in Kenya and the extent of their conformity to International Financial Reporting Standards. It also seeks to investigate the reasons why some small trade enterprises succeed while some close shop. An analysis of how small traders in Kenya keep business records, whether these records are in written form or are held in the memory of the trader, will inform the reasons behind the success of small trading in Kenya. It will also explain the extent to which accounting principles as outlined in the International Financial Reporting Standards are relevant to the small and micro enterprise.
\end{abstract}

Informal interviews with small traders in Nairobi, Nakuru and Kisumu were used to gather qualitative data.

The small and micro enterprises surveyed in the three towns exhibited similar patterns in their business operations. Some of the characteristics found in common include traders' sources of capital, the nature and style of business operations, and their business records maintenance. The findings indicate that these enterprises do have an accounting system. The written accounting records are limited to a list of debtors and business creditors. The other records are held in the traders' memory. This system makes it difficult to analyze data in this sector as information is elicited only through careful inquiry and discussion with individual traders. The results of the findings also indicate that trading in this sector is profitable just like the other business in the formal sector. Lack of written accounting information makes it difficult to carry out financial ratios relating to profitability. 
Key words: accounting systems, accounting principles, small and micro enterprises, International Financial Reporting Standards.

\section{Introduction}

The proliferation of small and micro enterprises and their significantly large numbers in subSaharan Africa is much greater than official statistics indicate. It is estimated that up to $30 \%$ of the working population in sub-Saharan Africa is employed in this sector (Mensah et al, 2007). In the World Bank Report on 2009 World Development Indicator (The Report), there is a great emphasis for governments in Africa to improve infrastructure as a means of spurring economic growth and reducing poverty. The Report further states that development and investments are critical for poverty reduction and that private investment has tremendous potential to contribute to economic growth. The private sector is also deemed to be the engine of productivity growth, job creation and a generator of higher incomes. Investments in this sector will result in the provision of basic conditions that empower poor people by improving health, education and infrastructure.

The Report makes mention of the fact that data used in development of economic indicators is compiled from publicly available information. Unfortunately, data relating to local, small and micro scale enterprises are omitted in these analyses because they are not publicly reported. Much as it is said that entrepreneurship is essential to the dynamism of the modern market economy, and that a greater entry rate of new businesses can foster competition and economic growth, small and micro enterprises are most of the times created to meet immediate family needs and may not be registered (not appearing in the country's registrar of companies records) which is a basis for calculating the number of business enterprises in a country as well as the volumes of revenue tracked through the national tax return regimes.

Not much attention has been paid to this sector of the economy involving small and micro enterprises, which on one hand is claimed to significantly contribute to economic growth and 
reduction of employment, and on the other hand is a sector left out when recording official statistics relating to trade in Kenya. The result therefore is that little is known about their operations and especially the nature of the accounting systems that exist in these enterprises. As a result it is difficult to concretely determine the monetary value of their contribution to the economy.

The Financial Crisis Advisory Group (www.ifrs.org/News/Press) ${ }^{1}$ identifies "Effective Financial Reporting" as one of the key principles that "plays an integral role in the financial system by striving to provide unbiased, transparent and relevant information about economic performance and condition of businesses." Effective financial reporting, the Group further states is of great importance to a wide range of users including investors, regulators for tax policy formulation and other financial market participants in their resource allocation such as commercial banks, microfinance institutions.

This paper analyses a limited survey of small and micro enterprises in Nairobi, Nakuru and Kisumu towns in Kenya. A small and micro enterprise is defined here as an outfit which is run by the sole proprietor and has zero to ten employees. There are two broad questions addressed in this survey. The first question relates to the capital structure of these enterprises and the second relates to their accounting systems. This includes analyzing the accounting cycle, nature of expenses and record-keeping practices. In addressing these questions this paper will consider whether there is merit to further investigate and recommend documentation of data in this sector and also review from an economic point of view the aggregate contribution of the actors in this sector in economic areas such as employment, access to education, and their role in poverty reduction.

This paper is in three sections. The first section describes/reviews the characteristics of small and medium enterprises and the applicability of accounting standards in these enterprises. The second section describes the sample and the survey of the enterprises. The third section presents

\footnotetext{
${ }^{1}$ The Financial Crisis Advisory Group is a high level group of recognized leaders with broad experience in international financial markets. It was formed at the request of the International Accounting Standards Board and the US Financial Accounting Standards Board to consider financial reporting issues from the recent global financial crisis.
} 
the results of the assessment of these enterprises in response to the two questions relating to their capital structure and the accounting systems. Finally the conclusions drawn are presented.

\section{Significance of the Study}

The findings of this research paper are significant because the analysis of these findings will reveal whether the systems of book keeping by small traders in their current form reflect accounting principles and practices adopted by the formally organized institutions. The findings will explain how small traders define business success in monetary terms and how relevant accounting is to traders in small and micro enterprises in Kenya. They will also make a case for inclusion of the small and micro enterprises in the business sector data for use in economic statistics.

\section{Characteristics of Small and Micro Enterprises}

According to Lawrence et al, (2006), the literature on accountability and sustainable business practices has mainly focused on the large, usually multi-national, companies that have significant economic impact. Micro and small enterprises have little impact when considered individually, but when considered collectively their impact may be significant and should not be ignored. They further state that the question of the sustainability of the business practice for small and micro entities is not clear and is hard to trace the sustainability responsibility to individual proprietors.

The continued growth of the small and micro enterprise sector in sub Saharan African is an indication that their operations are profitable; given that all profit making companies survive in the market as long as they remain profitable (Caruthers and Espeland, 1991). According to Ozar et al (2008) there has been a growing interest and attention in the role small enterprises play in the economy since the 1980s. One of the reasons for this considerable attention is that these enterprises have been found to have potential to generate employment and also to contribute to poverty alleviation in most countries in sub-Saharan Africa where social environments have worsened overtime due to increasing levels of unemployment as well as increasingly widening gaps of income inequality. Biggeri et al (1999) further note that small and micro enterprises 
have been credited for providing local opportunities and turning local savings into local investments.

That fact that small and micro enterprises have played and continue to play a significant role in economies in sub Saharan African cannot be overemphasized. According to Newberry (2006) the micro and small enterprises have been lauded from time to time for making significant contributions to the economy in their small ways. However, they are usually ignored by governments when it comes to policy and regulation formulation and by the big non-profit and microfinance institution when they shift to medium scale. Medium scale here refers to those enterprises that are able to employ 10 to 250 employees. Mensah et al (2007) categorize the micro, small and medium enterprises as follows: a micro enterprise as one with 1-5 workers, a very small enterprise with 6-9 workers and a small enterprise as one with less than 30 workers, and medium enterprise having as many as 250 workers.

Given that the small and micro trade enterprises miss out on both ends - governments and nonprofits and microfinance institutions, the result is paucity of information regarding their operations. Furthermore, it is the dearth of information on these small and micro enterprises that makes it hard to determine in quantifiable terms the extent and level of their contribution in the economies in sub Saharan Africa. Most traders in the small and micro enterprises do not keep written records of their activities; they simply keep mental records (Mensah et al, 2007). Their focus is mainly on the amount of funds to be allocated to buy new stock, to pay creditors and to keep a record of debtors related to the business. This lack of a written account and combined with the lack of skills in book-keeping only complicates the matter of data collection in this sector.

In many countries the savings to initiate micro and small enterprise business for economic survival for members of society has been in place in for a long time. According to Seibil (2001) the existence of organizations involving rotating savings dates as far back as the 16 century. He further states that these revolving savings funds can be found in virtually all communities globally and are part and parcel of the local micro economy and each community has a term in local language to refer to these informal institutions. Examples include, the hui system in China, 
chit funds in India, the arisan in Indonesia, the paluwagan in the Philipines and the grameen banks in Bangladesh, gameya in Egypt, ekup in Ethiopia. In Kenya these informal revolving funds are referred to as chama. These simple credit systems have been created on the basis of the need to develop and implement principles of self-reliance, viability and sustainability. A factor that could have contributed to their proliferation is the absence of help from the formal finance. The formal banking sector also has stringent requirements on the borrower making it difficult for most people unable to meet the set requirements to access funds on credit. Sivramkrishna and Panigrahi (2001) further postulate that self help groups have created an alternative to formal financial institutions. A self help group is set up when a number of persons agree to pool funds to make them available to one member of the group at a time in a revolving manner (Chiteji, 2002).

In Europe, little savings in households and in small enterprises have over time contributed to the growth and development of the micro finance sector outside the financial systems (Seibel, 2001). The system of obtaining credit on the basis of amount of funds saved has proved to be viable and sustainable. Seibel (2001) further notes that the micro and small enterprises have for many years provided an easy and cheap facility for simple households to borrow and carry out business activities that contribute to overall economic development. According to Chiteji (2002) this system of pooling funds does not always work as there is usually no formal contract when the groups are formed. He further states that in most cases informal groups enforce compliance and continued membership thanks to social collateral. Social collateral is a deterrent to payment and contribution default by members as default would lead to exclusion in any other group membership the member my attempt to join in future. It is a form of social audit through which members are able to check the integrity of each other within the group.

According to Aryeetey et al (1994), many of the small and micro enterprises begin their operations with very small amounts of capital built from personal savings. Their growth depends on the steady build up of their businesses achieved through reinvesting profit/cash left over after meeting all business, personal and family expenses. 
Aryeetey et al (1994) states that the reason for this lack of attention is because most of the financial and economic studies have, over time focused on the macroeconomic issues such as taxation, inflation, gross domestic product, employment and interest rates. These macroeconomic factors while important, do not directly affect the micro and small businesses as they are always regarded to be below the threshold of data collection when it comes to macroeconomic analysis. However, they cumulatively form a formidable vehicle for cash flow generation and circulation with the economy (Bowen et al, 2009). Studies have not been focused on the understanding of the micro economic factors that affect the micro and small enterprises in terms of how they start, evolve and their operations and /or phasing out of the market. Little attention has been paid to the operations and dynamics of the micro and micro enterprises despite having been lauded numerous times for making major contributions to economies in the sub-Saharan Africa.

One of the arguments explaining the survival of small and micro enterprises especially in hard economic times is that they are flexible and agile which enables them to easily adapt to the fast and frequently changing demands of clients. Large and medium enterprises on the other hand are forced to scale down operations and close down part of their activities during hard financial and economic times. They are unable to cope with rapid changes in the conditions of demand and supply within which they operate. The nature of assets in large and medium enterprises are fixed and tied in items such as highly specialized stocks with a target clientele, machinery and equipment, land and buildings. These are not easily convertible into cash making it difficult to rapidly adjusts when the external business environment changes.

According to Biggeri et al. 1999, small and micro enterprises do not enjoy economies of scale. They, however, have the advantage of quickly adjusting to competitive pricing and have a high speed of adoption to innovation. This flexibility enables them to survive and continue operating profitably alongside the multinationals. However, not all the small and micro enterprises are able to adapt to external changes. Those that do not adopt fast enough to a fast-paced economic environment quickly become unprofitable and fall out of business.

In the next section we shall review the accounting and financial operations that exist in small and micro enterprises. 


\section{Accounting principles and the new SME standards issued by IFRS}

In their detailed paper on accounting for rationality Caruthers and Espeland (1991) state that over time it has been noted that for-profit enterprises would not survive if they were not sufficiently profitable. They further state that those that embraced the double entry system of accounting enjoyed a technical advantage over those that did not; and the entities that did not adopt this system of accounting would in the long run be driven out of the market. According to Frazer (1929) accounting is an application of economics. Trading is an economic activity involving various elements of in its transactions and therefore there must be a form of accounting system that is maintained.

According to Caruthers and Espeland (1991) accounts constitute part of the conceptual toolkit that persons in business use in reflecting results or effects of their past decisions in considering present alternatives by providing technical information on outcomes of previous business actions. The central role played by accounting in rational decision-making is also emphasized in modern accounting textbooks. They further argue that accounts can render an accurate assessment of the relative success of a particular investment and thereby facilitate the pursuit of higher profits. In addition, they also provide a record of current assets and are therefore used by businessmen and women as an indicator of economic means at their disposal. Accounts are therefore a critical factor in making rational financial decisions and consequently contribute to the maximization of profits. Kinney (2001) posits that accounting is one of the important type of information for decision makers both within and external to the organization. He further states that the quality of this information is equally important. The quality of information is gauged by its relevance and its reliability for a particular decision.

What accounts provide is the information necessary to measure and compare the alternatives and the selection of the alternative associated with the highest expected payoff. They allow someone to estimate the probabilities of success and the possible payoffs related to the various alternatives. 
Accounting is a technique that helps to organize and make sense of the business world. It would be extremely difficult, if not impossible, to conduct business without due order or recording. And this explains why some small and micro enterprises in Kenya fail; most often it is because they cannot tell the money/financial status of their business. (Bowen et al, 2009).

According to Caruthers and Espeland (1991), people have kept records for as long as they have engaged in buying and selling. Accounts in some form or other go back at least as far as 2300B.C in Egypt and 10000 B.C in pre-Mesopotamia. In both cases these early accounts served mainly to assist the memory of the businessman. Names, dates and nature of transaction, the transacting parties and other details would be noted. Persons with long term obligations, complex transactions, or simply poor memory would use accounts as little more than mnemonic devises. Accounting records would help the proprietor of business determine what he owed and how much work had been done in monetary terms. However, according to Penno (1990) the absence of accounting numbers in the small and micro trading business does not imply the absence of an accounting system. He further states that accounting numbers do not always capture all aspects of an enterprise. For a long time accountants ignored many economic activities which in their view could not be measured in financial terms. This is despite the fact that these activities were an important factor in the measurement of capital employed.

Over time, accounting became increasingly important because it was now a primary source of information, for the growing business empires for early merchants (Caruthers \& Espeland, 1991). Consequently, accounts had to be more systematic and complete to do more than just fill the gaps in someone's memory and a standardized format was developed for accounting for transactions for businesses in various locations. They further state that for a trader, knowing how to keep good and orderly records teaches one to draw contracts, how to do business and how to obtain a profit. For this reason, a merchant must not rely upon memory, for such reliance has caused many persons to err.

As a proprietor, one need not be concerned about making clear distinction between business affairs and private or personal ones. Living and trading were not separate spheres of activity, 
and the specific source of an expense or revenue was of little consequence. This distinction becomes problematic when more than one person has invested in a firm or a proprietor has more than one business premise, Caruthers and Espeland (1991).

From their findings Bowen et al (2009) note that disciplined finance management was cited as one of the challenges facing SMEs. This can be closely linked with non maintenance of a written record of all money transactions relating to business activities. The consequence being, that the proprietor is unable to trace all income and expenses. This may be due to poor memory or pilferage where one employs more than one worker without stringent record-keeping habits.

According to Bowen et al (2009) only 47\% of the respondents in their survey considered financial management knowledge as a hindrance to growth to the micro and small business trade. This implies that 53\% did not consider financial management resulting from accounting record keeping as important for the success of their enterprise.

Mensah et al (2007) states that a significant number of enterprises in their survey kept no records pertaining to operations reports, financial reports, audited accounts, tax returns reports, and so on. Until recently, all the micro and small enterprise could not receive credit from the banks and promotional institutions due to the fact that the formal banking sector considered them a high risk area, and hence the high cost of borrowing from the banks for the micro and small businesses. Some microfinance institutions have ventured into small loans and credits to this sector. According to Jeppesen (2005), once credit is advance to the traders only the lender keeps the books of creditors on their part and in most cases the borrower does not keep a written account of this loan or credit. Most lenders divide these payment amounts into tiny amounts that enable the borrower to pay up on daily basis. For the lender, the trade process the borrower goes through to raise the repayment amount is not key as long as the amount is paid and with interest.

Aryeetey et al (1994) in assessing the financial statements of micro and small enterprises there are practical problems in deriving the records and figures that make up these statements. This is because for almost all enterprises the owners keep all the records in memory and hence the lack of records of all kinds - sales, marketing, accounting, credit borrowing from lending 
institutions, staff costs, owners emoluments, etc. Proprietors of micro and small enterprises keep no systematic records and are therefore unable to provide data over the period since their creation of their entities.

In July 2009 the International Accounting Standards Board (IASB) published the International Finance Reporting Standard for Small and Medium sized Entities (IFRS for SMEs). The objective of this standard was to enable similar Small and Medium sized Entities across the world to produce comparable accounting information by taking into account the needs of SMEs in terms of costs involved in presentation of financial statements and the benefits provided to the users of these statements. In its adoption of the IFRS for SME the Institute of Certified Public Accountants of Kenya (ICPAK 2009 defines an SME in Kenya as an entity that" (a) does not have public accountability; (b) publishes general purpose financial statement for external users e.g. owners not involved in day to day management, Kenya Revenue Authority, existing and potential creditors, credit rating agencies and (c) whose debt and equity instruments are NOT traded in the public market (A domestic or foreign stock exchange or over the counter market" (www.icpak.com). ${ }^{2}$

The development of the IFRS for SMEs by the International Accounting Standards Board is welcome move to standardize financial reporting in this sector, the threshold for SME remains high thus excluding a significant majority of small and micro enterprises which when combined represent a high volume in financial and/or monetary terms. While it is a good starting point for a move towards accounting standard that include most business entities that contribute economic development, the impact and results of the implementation of this IFRS for SMEs in countries in sub-Saharan Africa might take the next couple of years. http://www.ifrs.org/News/Features/Africa+embraces+IFRSs.htm ${ }^{3}$

Even as new accounting standards are gradually developed to cope with the new developments in accounting and financial management in the world as a result of changing business environments, accounting standard setters must consider all actors in economic growth and

\footnotetext{
${ }^{2}$ This is the website for the Institute of Certified Public Accountants of Kenya.

${ }^{3}$ This is the website for the International Financial Reporting Standards.
} 
development. As Caruthers and Espeland (1991) posit, "accounts frame an economic reality in a particular way". They further argue that accounting plays a critical role in shaping economic development resulting from changing demands in changing publics and therefore an important role in investment decision making. The SME standard under the IFRS is a great step in incorporating all business players in all economies but a lot needs to be done by law making institutions relating to businesses that are important, yet excluded from statistics used in decision-making in areas directly affecting the small and micro enterprise sector.

The next section assesses the state of small and micro enterprises in Kenya following the survey carried out.

\section{Assessment of Small and Micro Enterprises}

In Kenya, the current magnitude of the micro and small enterprise sector which comprise of vegetable vendors trading in temporary kiosks, mobile street venders of a variety of merchandise, is unknown. Most of these micro and small enterprises lack formal premises in buildings and operate from residential premises, open spaces or in wooden kiosks/sheds. In most cases these are places where the customers are located or where the clients easily find them by default. The operations of these micro enterprises are illegal in most cities and their activities are not provided for the city or town by laws.

From the informal interviews carried out among the micro and very small enterprises, the characteristics that distinguish this sector are as follows:

\section{Capital structure}

Most owners of small and micro enterprises start by saving up little amounts of money on a monthly basis in order to raise initial capital to enter into the small and micro enterprise sector. For ninety nine percent of the informants, raising the initial capital was the biggest challenge. Some had to work as farm laborers for a year or two, some as house helps (domestic workers), others saved funds by making careful and economical purchases from kitchen money provided by their working spouses. The amount saved to start the various business enterprises ranged from $\$ 60$ to $\$ 250$ depending the business activity the proprietors intended to undertake. The 
types of businesses in the small and micro enterprise sector vary within the sector. There are those that sell locally made crafts such as baskets, traditional jewelry, table mats and wall hangings. There are stalks with second hand clothes, shoes handbags and other household wares. Others vend a variety of fast selling fruits and vegetables which form the staple diets of people living in these towns. Others still sell foods and refreshments to cater to the crowds coming into the market and to stall owners. These include juice, tea porridge sliced fruits, fruit salad, lunch time meals including ugali (a paste made from boiling water and maize flour) and vegetables, and githeri (boiled maize and beans). There is also the vending of a variety of motor vehicle and household appliances by hawkers who sell by walking up to the client in the hope of making a sale. These amounts only enable them to purchase the first batch of stock items to start their trade. The small and micro businesses do not have permanent business premises. They operate from roadside stalls that are dismantled at end of day, some hawk their wares along the highways motorists waiting at traffic lights, others from office to office and from house to house. Those in ready to eat food business set up next to big construction sites during meal times (morning and lunch time). The meals sold by these vendors comprise of porridge made from maize meal, ground millet and sorghum, ugali and local vegetable stew, githeri and chapati (an unlaven cake made from wheat flour. In some building in the city centers, the owners have subdivided the premises into temporary stalls of about nine square meters, which they hire out and collect rent on a daily basis.

These markets address a deficiency that medium sized and big supermarkets cannot cover. They bring the market to the people and are able to package their merchandize into quantities their target clientele are able to pay for in cash. They are able to sell one tomato, one onion, a slice of cabbage, twenty grams of detergent, twenty grams of cooking fat, a slice of pineapple and a slice of a watermelon.

\section{Operations and accounting system}

A vast majority of the small and micro enterprises are owner-run usually with no employees. Through formation of clusters of similar enterprises in geographic proximity, the owners form revolving savings funds to which members contribute small equal amounts on a daily basis. The funds collected from each member are given to members in turns until each member receives a 
lump sum amount in contribution in every turn. These funds play a critical role in helping the business owners maintain and build up their businesses. The revolving savings funds operate on a trust basis. Very few of these enterprises receive credit from commercial banks. Some micro finance institutions have targeted this sector as their business niche. One such firm advances credit to the owners of these very small enterprise for amounts ranging from US\$40 to US\$250. Payment arrangements are discussed and agreed upon between the lender and the borrower. In the payment arrangements the loan amount plus interest should be paid in daily installments at the end of each working or business day. The collateral for these loans although not formally charged is the business merchandise the enterprise owners hold. The micro finance institutions confirmed that the default rate rarely gets to $1 \%$ of the amount lent out.

The small and micro enterprise sector is a fluid one. A business enterprise may be here today and gone tomorrow. Since these enterprises are created to solve family financial constraints, one major family catastrophe, a terminal disease requiring expensive medication, death of the owner could led to the exit of the business from the market. Other factors that affect the small and micro enterprises existence is are political unrest, change in city laws, and change in monetary and fiscal policies. Enterprises in the informal sector operate under harsh business environments. They are often required to pay many fees and licenses to city councils and municipalities. The regulations on collection of fees and licenses are often irregularly and inconsistently. Haphazard checking of licensing by the council and municipality staff are unannounced often taking the traders off guard. Lack of trading license or the non display of a receipt on fees paid may result in confiscation of the trader's merchandise. In addition the traders are required to pay heavy fines for non-compliance leading to major losses on the trader's part. This is not to advocate for illegal trade or non-compliance in laws and regulations of the city and municipal councils. Rather, policy makers and council administration have to work to ensure a conducive and enabling business environment through the establishment of a regulatory framework within which small and micro traders operate. The rules also should be clear to all and consistently applied to ensure orderly conduct of trading activities in the small and micro sector. Most traders interviewed were in the opinion that the councils (civic administration) in towns where they operated provided inadequate support businesses in the informal sector. 
In most cases fiscal and monetary policies are geared more towards revenue collection rather than provision of tax incentives. Tax planning should also consider this sector or the economy with a view of providing tax incentives that foster growth. This would in turn develop into a revenue collection at clearly defined thresholds. The contributions of informal sector should also be factored in during the development of fiscal policies to spur growth in this sector often touted to make substantial contributions to economic growth and poverty reduction. Monetary policies should be developed to regulate micro finance institutions and a certain segment of the formal banking sector to cater for the small and micro traders.

The accounting in these enterprises is on cash basis and most proprietors have no bank accounts. Perhaps due to stringent requirements to open bank accounts and besides they need every coin to plan and meet all the business and family expenses at the early stages of business operations. No formal accounting records are maintained and records are kept mainly through memory and the records kept are those of debtors with dates indicating the date of borrowing and due date for likely payment. Business sales income generated by the small and micro enterprises is used for stock repurchase, and family use in education for immediate and extended family, housing, and revolving savings fund for informal groups in which persons from similar business or localities form instead of saving their funds in banks. The members contribute to the chamas faithfully and also repay their creditors on a timely basis. Others still resort to borrowing from money lenders where they borrow against a piece of property such as at television set, documents of asset title acting as collateral. Shylocks charge an exorbitant rate of interest and most people go to them as a last option to access funds. However, most wholesale suppliers prefer to deal on cash basis and have little or no credit business. The reason being that they know this is the only opportunity they have to get themselves and their families out of poverty. They are afraid of losing their wares, the only means of livelihood and hence their high levels of compliance.

In small and micro enterprises stock items traded are of a wide variety and these include foodstuffs (fish, fruit salad, roast maize, assorted vegetables, ready to eat food, milk), home appliances and new and used clothing, and other products easily consumed by the formally employed population. 
Most small and micro enterprises operate temporary shelters and do not have formal premises. The premises where these enterprises operate is along the roadside where most potential clients pass by in the evening after work, on highways whether they sale to motorists waiting for lights turn green or during traffic snarl-ups. Those in the city centre hire space (as small as four meter square) in an open hall for which they pay daily rents for the space for the day. Others still operate in premises that are set up early morning and dismantled at the end of the day and they carry their merchandise home for safe keeping.

According to the International Financial Reporting Standards-IFRS (www.iasb.org) ${ }^{4}$, a balance sheet shows the financial position of an entity at a given point in time. The main elements of a balance sheet are assets, liabilities and equity. Assets are the economic benefit that has the potential to contribute to the flow of cash and cash equivalent into the entity. Liabilities are obligations that arise in the normal course of business. The settlement of an obligation entails giving up resources to satisfy a claim on the entity's assets. Equity is the funds contributed by the owners and the retained earnings from the business at the end of an accounting period. The IFRS refer to an income statement as indication of the results of a business operation over a period of time. The income statement is a measure of performance and a basis of calculating the return on investment. The main elements in an income statement are income and expenses. Income increases economic benefits to an entity during an accounting period in the form of inflows or enhancement of assets. Expenses are decreases in economic benefits during a certain period in the form of outflows or depletion of assets. The excess of income over expenses gives rise to profit.

In accounting terms the balance sheet of these small and micro enterprises would look as follows:

\footnotetext{
${ }^{4}$ This is the website for the International Accountants Standard Board.
} 


\section{Balance Sheet}

\begin{tabular}{|c|c|}
\hline Assets & \\
\hline Non Current Assets & $\mathrm{XX}$ \\
\hline Current Assets & \\
\hline Cash \& cash equivalent & $\mathrm{XX}$ \\
\hline Trade receivables & $\mathrm{XX}$ \\
\hline Inventories (business merchandise) & $\mathrm{XX}$ \\
\hline Total Assets & $\mathrm{XX}$ \\
\hline & \\
\hline Equity \& Liabilities & \\
\hline Equity Attributable to Owner & \\
\hline Capital & $\mathrm{XX}$ \\
\hline Retained earnings (profit reinvested) & $\mathrm{XX}$ \\
\hline Total Equity & $\mathrm{XX}$ \\
\hline Non Current Liabilities & \\
\hline Long term loans & $\mathrm{XX}$ \\
\hline Total Noncurrent liabilities & $\mathrm{XX}$ \\
\hline Current Liabilities & \\
\hline Trade and other payables & $\mathrm{XX}$ \\
\hline Short term borrowings & $\mathrm{XX}$ \\
\hline Total Current Liabilities & $\mathrm{XX}$ \\
\hline Total Equity and Liabilities & $\mathrm{XX}$ \\
\hline
\end{tabular}

\section{Income Statement (daily)}

\begin{tabular}{|l|c|}
\hline Revenue & $\mathrm{XX}$ \\
\hline Cost of Sales & $(\mathrm{XX})$ \\
\hline Gross Profit & $\mathrm{XX}$ \\
\hline Expenses & $(\mathrm{XX})$ \\
\hline Profit for the period & $\mathbf{X X}$ \\
\hline
\end{tabular}

The empirical survey of this sector in three towns, Nairobi, Nakuru and Kisumu gave an indication relating to the characteristics of businesses in this sector. These include the sources of initial capital and subsequent access to credit, the nature of records kept by proprietors in this business sector, their extent of awareness and use of accounting. From the discussions with the various small and micro business owners, the above balance sheet and income statement reflect the accounting and book-keeping processes from a formal accounting point of view. 


\section{Ownership of business}

Most of the proprietors were sole - working in the business alone. Their reason for starting business being need for income to meet personal, immediate and extended family needs. The ages ranged from below twenty years of age to fifty years of age. Those below twenty years had been forced to drop out of primary or secondary school. Reasons ranging from lack of school fees, child headed families where both parents had died, need to support parents to take care of siblings by going in search of food, rent for shelter, medical care, etc. Most businesses are owner-run and fully managed. Most of the businesses fall in the Category of micro enterprises with one person running the business with in some cases one to five people working the proprietor. Business activities in this micro sector ranges from food vendors at business sites and construction sites, vegetable and fruit vendors at strategic road side bus- stops where people can purchase their merchandise as they go home at the end of the day from work, vendors of hardware, motor ware, bags, paintings, sunglasses, name it along the highway to motorists waiting for traffic lights to read go. Stock value in all these categories is usually between \$20 and $\$ 40$.

\section{Conclusions}

The study revealed small and micro enterprises do have an unrecorded accounting system. This accounting system is similar among virtually all the proprietors interviewed. On daily basis reconciliations include dividing the earnings/sales revenue for the day into funds for restocking, household needs, savings through revolving fund contribution and in some cases savings for investments (purchase of a property). Most of these enterprises are able to break even and make a profit.

The extra cash generated enables them to finance non business expenses such as foodstuffs for the family, medical expenses, school fees and school materials, house rent, clothing and other domestic needs. Small and micro traders create vehicles for money transfers within households and between family members thus, enabling them to meet various household needs. The exit from the market of traders in this sector is mainly attributed to diversion of business funds to finance other non business activities that may results from family calamities. In this case the 
trader is forced to close shop hoping to save up new start-up capital and reentry into the market. The death of the owner of the business also results in the permanent exit of the business from the sector, since by their inherent nature they are not going concerns.

With the proprietorship being concentrated to one person, the owner of the business, these small and micro enterprises are highly susceptible to shocks external to their businesses. Further this often ignored sector plays a highly significant role individually and collectively in poverty reduction. This sector makes a major contribution to poverty reduction and a significant contribution to economic growth, an outcome all development programs aspire to achieve. It contribution can be seen through the creation of small businesses, the raising of household incomes and the creation of markets for locally produced goods. Small and micro enterprises are embedded in the economic sector and serve a given clientele. This clientele has consumer needs not catered for by the medium and large enterprises.

The existence of informal trade in which small and micro enterprises thrive cannot be dismissed as transitory. Just as it is in the formal business sector, the survival informal sector is dependent on favorable monetary and fiscal policies, the cost of doing business and the availability of a market for their products. In brief, the success of any business depends on how it manages the rapidly changing external environment. Large enterprises, multi-national corporations, small and medium-sized enterprises and small and micro enterprises will continue to exist alongside each other. Each of these business operations caters for a certain market segment in the economy and their staying in the markets implies that they are profitable. It can safely be argued therefore that small and micro enterprises that extensively populate the informal sector are profitable operations just like the enterprises in the formal business sector. Unlike in the formal business sector, the absence of accounting data makes it difficult to carry out financial ratio analysis. The calculation of various financial ratios would provide a basis for gauging empirically the profitability level of the enterprises in the small and micro business sector. It would therefore be worthwhile to include this sector in economic statistical calculations in sub-Saharan African countries. 


\section{References}

B.G. Caruthers \& W. N. Espeland. 1991. Accounting for Rationality: Double-Entry Bookkeeping and the Rhetoric of Economic Rationality. The University of Chicago Press. The American Journal of Sociology Vol 97 No, 1.

E. Aryeetey, A. Baah-Nuakoh, T. Duggleby, H. Hettige \& W. F. Steel. 1994. Supply and Demand for Finance of Small Enterprises in Ghana. World Bank Discussion Paper No 251.

G. E. Frazer. 1929. Accounting in Italy. American Accounting Association. The Accounting Review. http://www.ifrs.org/News/Features/Africa+embraces+IFRS.htm

http://www.ifrs.org/News/Press+Release/Financial Crisis.htm

J.V. Mensah, M. Tribe \& J. Weiss. 2007. The small-scale manufacturing sector in Ghana: A source of dynamism or of subsistence income? Wiley InterScience. Journal of International Development.

M. Biggeri, D. Gembelli \& C. Phillips. 1999. Small and medium enterprise theory: Evidence for Chinese TVEs. Wiley InterScience. Journal of International Development.

M. Bowen, M. Morara \& S. Mureithi. 2009. Management of Business Challenges among Small and Micro Enterprises in Nairobi - Kenya. KCA Journal of Business Management vol 2 issue 1.

M. Penno. 1990. Accounting Systems, Participation in Budgeting, and Performance Evaluation. American Accounting Association. The Accounting Review.

N. Newberry. 2006. The Role of Small and Medium-Sized Enterprises in the Futures of Emerging Economies. http://earthtrends.wri.org

N. S. Chiteji. 2002. Promises Kept: Enforcement and the Role of Rotating Savings and Credit Associations in and Economy. Wiley InterScience. Journal of International Development.

S. Jeppesen. 2005. Enhancing competitiveness and securing equitable development: can small, micro and medium-sized enterprises (SMEs) do the trick? Development in Practice Vol 15 No 2 \& 4.

S. Johnson. 2004. The Impact of Microfinance institutions in local financial markets: A case study from Kenya. Wiley InterScience. Journal of International Development.

S. Ozar, G. Ozertan \& Z. B. Irfanoglu.2008. Micro and small enterprise growth in Turkey: Under the shadow of financial crisis. The Developing Economies (XLVI-4).

S. R. Lawrence, E. Collins, K. Pavlovich \& M. Arunachalam. 2006. Sustainability Practices of SMEs: the Case of NZ. Wiley InterScience. Business Strategy and the Environment.

S. Sivramkrishna \& R. Panigrahi. 2001. An Economic Model of Self-Help Groups: Policy Implications for Banks and NGO Initiatives. Wiley InterScience. Journal of International Development. 
W. R. Kinney Jr. 2001. Accounting Scholarship: What is Uniquely Ours? American Accounting Association. The Accounting Review.

www.iasb.org

www.icpak.com 